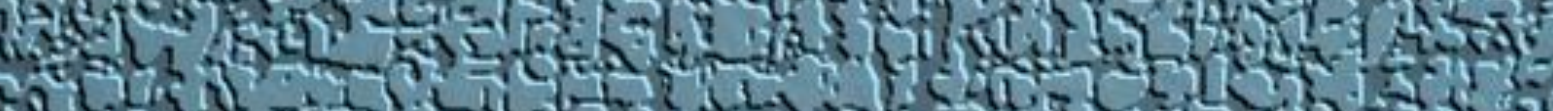

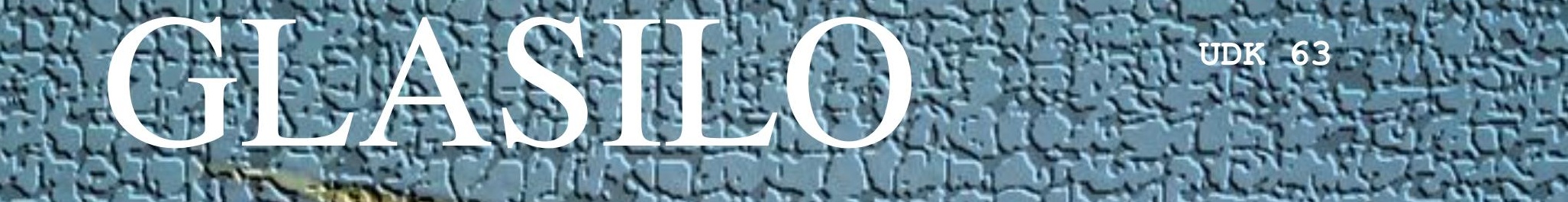

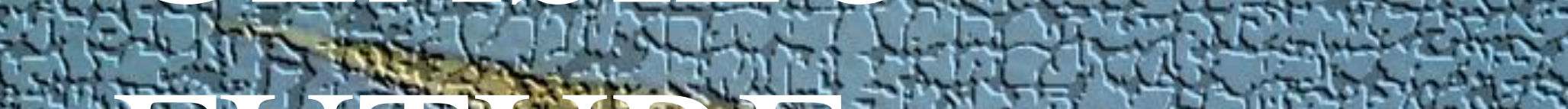
Ant

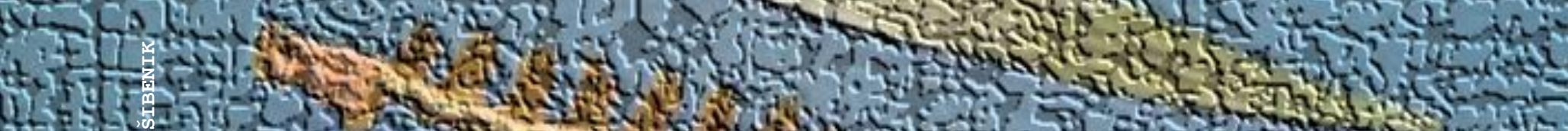

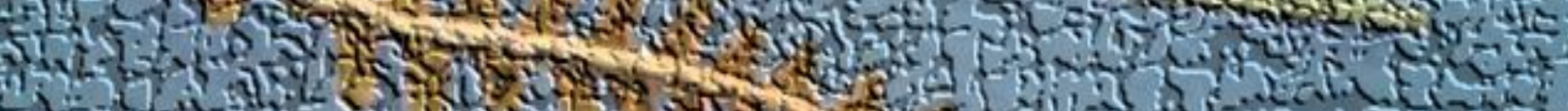
If

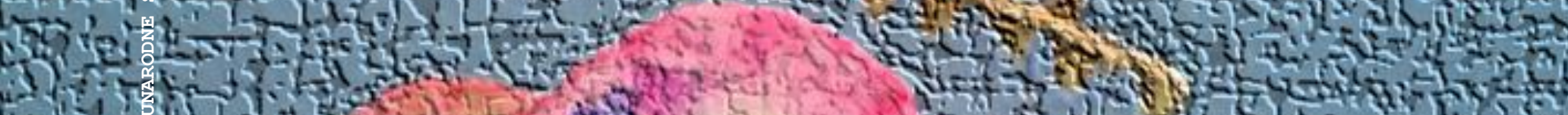

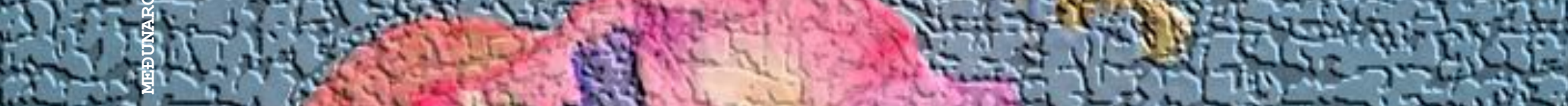

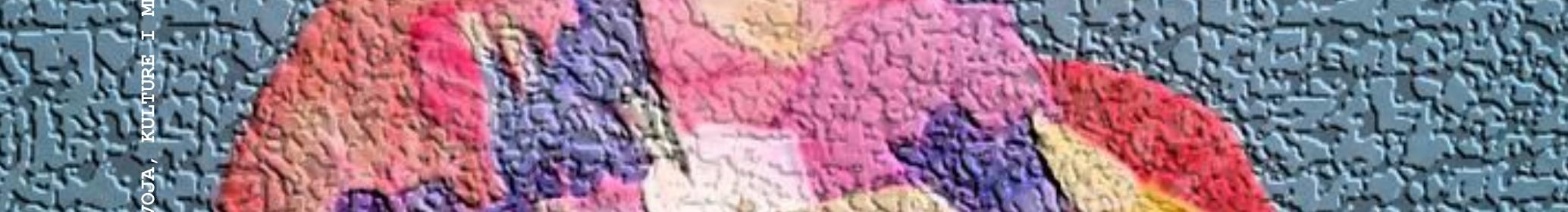
Nog

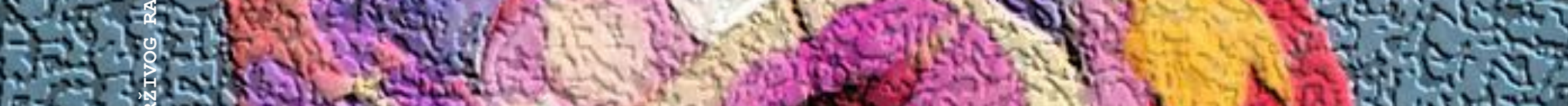

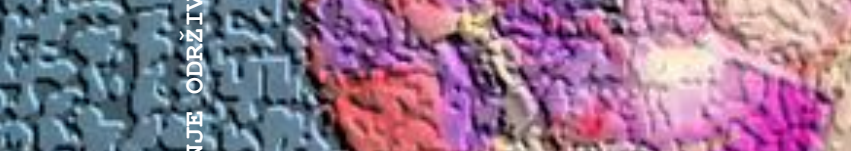
20. S. (2) (1)

1. (c) -

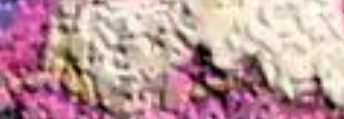
(3)

-1.

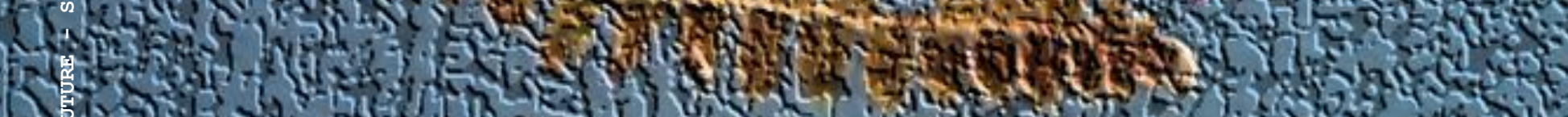
(n) So

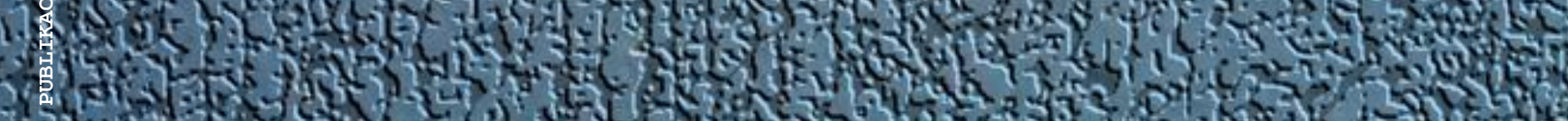
VoIUMgN 4 BRo $2-3$.

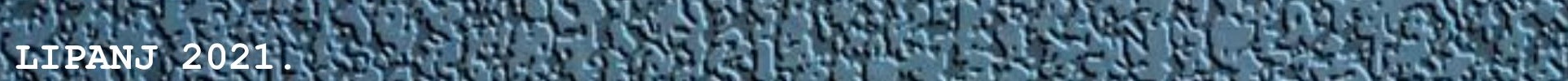

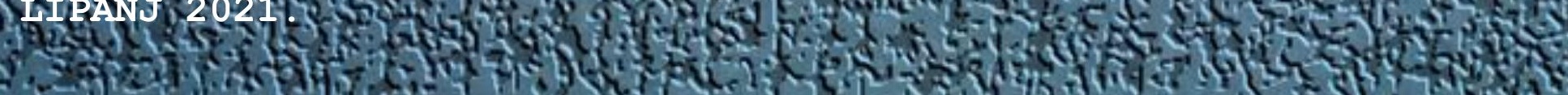




\section{Glasilo Future}

\section{Stručno-znanstveni časopis}

\section{Nakladnik: FUTURA}

\section{$F_{0 T} T_{0 R} A$}

Sjedište udruge: Šibenik
Adresa uredništva:

Bana Josipa Jelačića 13 a, 22000 Šibenik, Hrvatska / Croatia

㞗 / 息: +385 (0) 022218133

凹: urednistvo@gazette-future.eu / editors@gazette-future.eu

(3): www.gazette-future.eu

\section{Uređivački odbor / Editorial Board:}

Doc. dr. sc. Boris Dorbić, v. pred. - glavni i odgovorni urednik / Editor-in-Chief

Emilija Friganović, dipl. ing. preh. teh., v. pred. - zamjenica g. i o. urednika / Deputy Editor-in-Chief

Ančica Sečan, mag. act. soc. - tehnička urednica / Technical Editor

Antonia Dorbić, mag. art. - zamjenica tehničke urednice / Deputy Technical Editor

Prof. dr. sc. Željko Španjol

Mr. sc. Milivoj Blažević

Vesna Štibrić, dipl. ing. preh. teh.

Međunarodno uredništvo / International Editorial Board:

Prof. dr. sc. Kiril Bahcevandziev - Portugalska Republika (Instituto Politécnico de Coimbra)

Prof. dr. sc. Martin Bobinac - Republika Srbija (Šumarski fakultet Beograd)

Prof. dr. sc. Zvezda Bogevska - Republika Sjeverna Makedonija (Fakultet za zemjodelski nauki i hrana Skopje)

Dario Bognolo, mag. ing. - Republika Hrvatska (Veleučilište u Rijeci)

Prof. dr. sc. Agata Cieszewska - Republika Poljska (Szkoła Główna Gospodarstwa Wiejskiego w Warszawie)

Dr. sc. Bogdan Cvjetković, prof. emeritus - Republika Hrvatska (Agronomski fakultet Zagreb)

Prof. dr. sc. Duška Curić - Republika Hrvatska (Prehrambeno-biotehnološki fakultet Zagreb)

Prof. dr. sc. Margarita Davitkovska - Republika Sjeverna Makedonija (Fakultet za zemjodelski nauki i hrana Skopje)

Prof. dr. sc. Dubravka Dujmović Purgar - Republika Hrvatska (Agronomski fakultet Zagreb)

Prof. dr. sc. Josipa Giljanović - Republika Hrvatska (Kemijsko-tehnološki fakultet u Splitu)

Prof. dr. sc. Semina Hadžiabulić - Bosna i Hercegovina (Agromediteranski fakultet Mostar)

Prof. dr. sc. Péter Honfi - Mađarska (Faculty of Horticultural Science Budapest)

Prof. dr. sc. Mladen Ivić - Bosna i Hercegovina (Univerzitet PIM)

Doc. dr. sc. Anna Jakubczak - Republika Poljska (Uniwersytet Technologiczno-Przyrodniczy w Bydgoszczy)

Doc. dr. sc. Orhan Jašić - Bosna i Hercegovina (Filozofski fakultet Tuzla)

Prof. dr. sc. Tajana Krička - Republika Hrvatska(Agronomski fakultet Zagreb)

Doc. dr. sc. Dejan Kojić - Bosna i Hercegovina (Univerzitet PIM)

Slobodan Kulić, mag. iur. - Republika Srbija (Srpska ornitološka federacija i Confederation ornitologique mondiale)

Prof. dr. sc. Biljana Lazović - Crna Gora (Biotehnički fakultet Podgorica)

Prof. dr. sc. Branka Ljevnaić-Mašić - Republika Srbija (Poljoprivredni fakultet Univerziteta u Novom Sadu)

Doc. dr. sc. Zvonimir Marijanović - Republika Hrvatska (Kemijsko-tehnološki fakultet u Splitu)

Doc. dr. sc. Ana Matin - Republika Hrvatska (Agronomski fakultet Zagreb)

Prof. dr. sc. Bosiljka Mustać - Republika Hrvatska (Sveučilište u Zadru)

Hrv. akademik prof. dr. sc. Stanislav Nakić - Bosna i Hercegovina (Sveučilište Hercegovina Mostar)

Prof. dr. sc. Ayșe Nilgün Atay - Republika Turska (Mehmet Akif Ersoy University - Burdur, Food Agriculture and Livestock School) Prof. dr. sc. Tatjana Prebeg - Republika Hrvatska (Agronomski fakultet Zagreb)

Prof. dr. sc. Bojan Simovski - Republika Sjeverna Makedonija (Fakultet za šumarski nauki, pejzažna arhitektura i ekoinženering "Hans Em" Skopje)

Prof. dr. sc. Davor Skejić - Republika Hrvatska (Građevinski fakultet Zagreb)

Akademik prof. dr. sc. Mirko Smoljić, prof. v. š. - Republika Hrvatska (Sveučilište Sjever, Varaždin/Koprivnica, Odjel ekonomije)

Prof. dr. sc. Nina Šajna - Republika Slovenija (Fakulteta za naravoslovje in matematiko)

Dr. Marko Šare - Republika Italija (Hrvatska zajednica u Trstu)

Akademik prof. dr. sc. Refik Šećibović - Bosna i Hercegovina (Visoka škola za turizam i menadžment Konjic)

Prof. dr. sc. Andrej Šušek - Republika Slovenija (Fakulteta za kmetijstvo in biosistemske vede Maribor)

Prof. dr. sc. Elma Temim - Bosna i Hercegovina (Agromediteranski fakultet Mostar)

Mr. sc. Merima Toromanović - Bosna i Hercegovina (Biotehnički fakultet Univerziteta u Bihaću)

Prof. dr. sc. Marko Turk - Ruska Federacija (University of Tyumen)

Doc. dr. sc. Ivana Vitasović Kosić - Republika Hrvatska (Agronomski fakultet Zagreb)

Doc. dr. sc. Ana Vujošević - Republika Srbija (Poljoprivredni fakultet Beograd)

Sandra Vuković, mag. ing. - Republika Srbija (Poljoprivredni fakultet Beograd)

Prof. dr. sc. Vesna Židovec - Republika Hrvatska (Agronomski fakultet Zagreb)

Grafička priprema: Ančica Sečan, mag. act. soc.

Objavljeno: 30. lipnja 2021. godine.

Časopis izlazi u elektroničkom izdanju dva puta godišnje, krajem lipnja i prosinca, a predviđena su i dva specijalna izdanja tijekom godine iz biotehničkog područja.

Časopis je besplatan. Rukopisi i recenzije se ne vraćaju i ne honoriraju.

Autori/ce su u potpunosti odgovorni/e za sadržaj, kontakt podatke i točnost engleskog jezika.

Umnožavanje (reproduciranje), stavljanje u promet (distribuiranje), priopćavanje javnosti, stavljanje na raspolaganje javnosti odnosno prerada u bilo kojem obliku nije dopuštena bez pismenog dopuštenja Nakladnika.

Sadržaj objavljen u Glasilu Future može se slobodno koristiti u osobne i obrazovne svrhe uz obvezno navođenje izvora. 


\section{Glasilo Future}

\section{Stručno-znanstveni časopis}

FUTURA - stručno-znanstvena udruga za promicanje održivog razvoja, kulture i međunarodne suradnje, Bana Josipa Jelačića 13 a, 22000 Šibenik, Hrvatska

(2021) 4 (2-3) 01-85

\section{SADRŽAJ:}

Izvorni znanstveni rad (original scientific paper)

Str.

E. Delić, B. Dorbić, Alisa Adžemović

Dendroflora Donatim parka u Adapazariju/Sakarija - Republika Turska

Dendroflora of Donatım park in Adapazari/Sakarya - Republic of Turkey

\section{Pregledni rad (scientific review)}

Tatjana Prebeg, Kristina Balen, Vesna Židovec

Utjecaj anatomske građe latica na ukrasna svojstva cvjetova

The influence of petal anatomy on ornamental attributes of flowers

Jelica Galić

Značaj proučavanja stanovništva u cilju razvoja poljoprivrede - studija slučaja Županije

Zapadnohercegovačke

The importance of population studies for agricultural development - case study of the West

Herzegovina County

\section{Stručni rad (professional paper)}

D. Krstonošić, Franciska Erdelj, Ž. Škvorc, K. Sever

Odabir autohtonih aromatičnih i ljekovitih trajnica za uređenje terapijskih urbanih prostora na Mediteranu

Selection of autochthonous aromatic and medicinal perennials for therapeutic urban spaces in the Mediterranean

Dubravka Dujmović Purgar, Mateja Palčić, Klara Barić, D. Jareš, Z. Svečnjak Agronomska i gospodarska vrijednost facelije Agronomic and economic value of phacelia

\section{Nekategorizirani rad (uncategorised paper)}

B. Dorbić

Društvene vijesti i obavijesti

Social news and announcements

Zdenka Bilušić, B. Dorbić

Prikaz radionice

Review of workshop 
Tatjana Prebeg, Kristina Balen, Vesna Židovec / Utjecaj anatomske građe latica na ukrasna svojstva cvjetova / Glasilo Future (2021) 4 (2-3) 16-29

\title{
Utjecaj anatomske građe latica na ukrasna svojstva cvjetova
}

\section{The influence of petal anatomy on ornamental attributes of flowers}

\author{
Tatjana Prebeg $^{1 *}$, Kristina Balen ${ }^{1}$, Vesna Židovec ${ }^{1}$
}

pregledni rad (scientific review)

doi: $10.32779 /$ gf.4.2-3.2

Citiranje/Citation ${ }^{2}$

\section{Sažetak}

Boja cvjetova je jedan od glavnih elemenata estetske vrijednosti ukrasnog bilja te stoga ima veliko komercijalno značenje, naročito u cvjećarskih kultura. Iako boju cvijeta primarno određuju sastav i koncentracija pigmenata, na njene karakteristike utječu i drugi čimbenici, među kojima važnu ulogu ima i anatomska građa tkiva latica, osobito epiderme. U većine cvjetova, epidermalne stanice su barem na jednoj strani latica čunjasto ispupčene. Čunjast oblik stanica može povećati udio svjetlosti koji ulazi u tkivo latice i dospijeva do pigmenata, uslijed čega se povećava apsorpcija svjetlosti te time i intenzitet boje. Anatomska građa, međutim, osim na boju, utječe i na vizualne karakteristike površine (teksturu) latica. Epidermalne stanice čunjasta oblika laticama daju matirani ili baršunasti izgled, dok su latice s vrlo ravnom i glatkom epidermom sjajne površine. U ovome radu opisane su temeljne značajke anatomske građe latica te njihov utjecaj na dva važna čimbenika ukrasne vrijednosti cvjetova: boju i vizualne karakteristike površine latica.

Ključne riječi: anatomija latica, boja cvjetova, epidermalne stanice, mezofil, ukrasno bilje.

\section{Abstract}

Flower color is one of the key elements of aesthetic value of ornamental plants and therefore has large commercial significance, especially in floricultural crops. Although flower color is determined primarily by the composition and concentration of the pigments, the characteristics of color are also affected by other factors, including anatomical structure of the petals, in particular the epidermis. In most flowers, petal epidermis is composed of conically-shaped cells, on at least one side of the petals. Conical cell shape can increase the proportion of incident light that enters the petal tissue, so more light reaches the pigments; in that way, light absorption and thus the intensity of petal color are

\footnotetext{
${ }^{1}$ Sveučilište u Zagrebu Agronomski fakultet, Zavod za ukrasno bilje, krajobraznu arhitekturu i vrtnu umjetnost, Svetošimunska cesta 25, 10000 Zagreb, Republika Hrvatska.

*E-mail: tprebeg@agr.hr.

${ }^{2}$ Prebeg, T., Balen, K., Židovec, V. (2021). Utjecaj anatomske građe latica na ukrasna svojstva cvjetova. Glasilo Future, 4(2-3), 16-29. / Prebeg, T., Balen, K., Židovec, V. (2021). The influence of petal anatomy on ornamental attributes of flowers. Glasilo Future, 4(2-3), 16-29.
} 
enhanced. Anatomical structure, however, also influence the visual characteristics of petal surface (texture). Petals with conically-shaped epidermal cells have a matte or velvety surface, while a very flat and smooth petal surface appears glossy. This paper describes key features of petal anatomy and the ways in which they affect two important factors of ornamental value of flowers: petal color and visual characteristics of the petal surface.

Key words: petal anatomy, flower color, epidermal cells, mesophyll, ornamental plants.

\section{Uvod}

Cvjećarstvo je danas dinamičan i ekonomski važan dio hortikulturne industrije. Vrijednost cvjećarske proizvodnje u 2018. godini na globalnoj je razini iznosila 43,23 milijarde američkih dolara, pri čemu je Europa imala najveći tržišni udio na svjetskom cvjećarskom tržištu od 40,3\% (Coherent Market Insights, 2019). Očekuje se da će europsko tržište rezanog cvijeća od 1,35 milijardi dolara u 2019. godini do 2027. godine dosegnuti vrijednost od 1,83 milijarde dolara (Europe Cut Flowers Market, 2020). Na najvećoj svjetskoj burzi cvijeća (Royal FloraHolland u Nizozemskoj) najprodavanija cvjetna vrsta za rez u 2020. godini bila je ruža (Rosa x hybrida), a među pet vrsta s najvećim brojem prodanih primjeraka nalazili su se još i tulipan (Tulipa sp.), krizantema (Chrysanthemum x morifolium), gerbera (Gerbera jamesonii) i ljiljan (Lilium sp.) (Royal FloraHolland, 2020).

Komercijalna vrijednost cvjećarskih kultura ovisi o različitim svojstvima biljaka, među kojima je jedno od najvažnijih boja cvjetova (Boutigny et al., 2020; Giovannini et al., 2021). Boja često ima presudnu ulogu u odabiru cvjetnih vrsta (Behe et al., 1999; Kelley et al., 2001), pri čemu sklonost kupaca prema određenoj boji ovisi o čimbenicima poput dobi i spola, a kod vrsta koje se rabe za rez, i prigodi za koju se nabavljaju (Behe et al., 1997; Yue i Behe, 2010). Primjerice, u istraživanju koje su među uzgajivačima ruža i potrošačima proveli Waliczek et al. (2018) najviše ispitanika je za uzgoj u vrtovima preferiralo ruže crvenih cvjetova, nakon kojih su po popularnosti slijedile ružičasta $i$ purpurna boja, dok je najmanje ispitanika bilo sklono plavoj boji. Gotovo 80\% ispitanika starije životne dobi preferiralo je ruže crvenih do crvenonarančastih cvjetova, dok su mlađi ispitanici češće bili skloni odabrati i druge boje.

Boju cvjetova primarno određuju pigmenti - tvari koje selektivno (tj. samo na određenom valnom području) apsorbiraju vidljivu svjetlost, dok elektromagnetsko zračenje ostalih valnih duljina u vidljivom dijelu spektra reflektiraju ili propuštaju. Primjerice, žutu boju cvjetovima daju pigmenti koji apsorbiraju svjetlost u plavom i zelenom području spektra, dok svjetlost u žutom području spektra reflektiraju ili propuštaju. Glavne skupine pigmenata odgovornih za boje cvjetova su flavonoidi, karotenoidi i betalaini (Tanaka et al., 2008; Młodzinska, 2009). Među njima najvažniju skupinu čine flavonoidi koji cvjetovima mogu dati čitav niz boja, od crvene, ružičaste, purpurne i plave (antocijanini), do žute (auroni i kalkoni) i blijedožute (flavoni i flavonoli) (Iwashina, 2015; Ohimya, 2018). 
Za boju većine žutih i narančastih cvjetova odgovorni su karotenoidni pigmenti koji se dijele u dvije skupine: narančasto-crvene karotene i žute ksantofile (Kishimoto et al., 2007; Ohimya, 2011). Betalaini cvjetovima daju žutu (betaksantini) ili crvenoljubičastu (betacijanini) boju, a prisutni su samo u vrsta reda Caryophyllales (u kojih zamjenjuju antocijanine) (Pavoković i Krsnik-Rasol, 2011; Polturak i Aharoni, 2017). Različit sastav pigmenata uzrokuje razlike u tonu boje, dok razlike u koncentraciji pigmenata mogu promijeniti intenzitet boje (Nakayama et al., 2004; Tanaka et al., 2008; Ohimya, 2018). Na karakteristike boje međutim može utjecati i sredina u kojoj se pigmenti nalaze (pH-vrijednost vakuole, prisutnost kopigmenata i iona metala) (Mol et al., 1998; Yoshida et al., 2009; Schreiber et al., 2010), razmještaj pigmenata u tkivu (van der Kooi et al., 2016), ali i anatomske karakteristike tkiva latica, pri čemu osobit značaj ima oblik epidermalnih stanica (Kay et al., 1981; Noda et al., 1994).

Epiderma je kod većine vrsta, barem na jednoj strani latica, građena od stanica koje se čunjasto izbočuju iznad površine tkiva (Kay et al., 1981; Weberling, 1989; Mudalige et al., 2003; Whitney et al., 2011; Weryszko-Chmielewska i Sulborska, 2012; Papiorek et al., 2014). Smatra se da čunjast oblik stanica povećava udio svjetlosti koji dospijeva do pigmenata uslijed čega se pojačava apsorpcija svjetlosti te time i intenzitet boje (Kay et al., 1981; Noda et al., 1994; Gorton i Vogelmann, 1996; Gkikas et al., 2015). Građa tkiva latica, međutim, osim na boju, može utjecati i na vizualne karakteristike površine (teksturu) latica. Primjerice, vrlo ravna i glatka epiderma može djelovati kao zrcalo, što laticama daje sjaj, dok epidermalne stanice čunjasta oblika laticama mogu dati baršunasti izgled (Vignolini et al., 2011, Vignolini et al., 2012; Zhang et al., 2015; van der Kooi et al., 2019; Stavenga et al., 2020). U ovome radu opisane su osobitosti anatomske građe latica te kako one utječu na dva važna čimbenika estetske vrijednosti cvjetova: boju i vizualne karakteristike površine latica.

\section{Osobitosti anatomske građe latica}

Latice se po svojoj anatomskoj građi većinom znatno razlikuju od lapova i pravih listova. Kod više od $75 \%$ dosad analiziranih vrsta kritosjemenjača, epiderma je barem na jednoj strani latica sastavljena od čunjasto (ili u nekih vrsta kupolasto) ispupčenih stanica (Slike 1a i b) (Kay et al., 1981; Whitney et al., 2011). Takvu epidermu latice obično imaju na strani koja je vidljiva oprašivačima kada prilaze cvijetu (uglavnom adaksijalna strana), iako se kod nekih vrsta može nalaziti i na drugoj strani latice (Whitney et al., 2011).

Čunjaste epidermalne stanice mogu u različitih vrsta biti različite veličine, ali se i znatno razlikovati s obzirom na visinu i nagib ispupčenog dijela (papila), pa stoga i oblikom mogu prilično varirati (Mudalige et al., 2003; Whitney et al., 2011; Papiorek et al., 2014). Najčešće imaju blago konkavne vanjske stijenke i zaobljen vrh. U bazalnom su dijelu obično ponešto proširene, dok im je unutarnja stijenka konveksno izbočena (Slika 1b). Bazalni dio stanica većinom je heksagonalna oblika, no može biti i više zaobljen, nepravilna oblika ili izdužen (Slika 1c) (Kay et al., 1981; Whitney et al., 2011). 
U nekih su latica (posebice u onih nježnije građe) antiklinalne stijenke epidermalnih stanica valovite, a nerijetko formiraju i uvrnuća (Slika 1c), što vjerojatno ima ulogu mehaničkog učvršćivanja (Eames i MacDaniels, 1925; Fahn, 1982; Weberling, 1989; Borowska-Wykręt i Kwiatkowska, 2018). Zbog uvrnuća stijenki kod nekih vrsta u epidermi nastaju međustanični prostori koji su u vezi s međustaničnim prostorima u unutrašnjosti latice. Na površini latice su ovi međustanični prostori obično prekriveni kutikulom i nisu u izravnom dodiru s vanjskom atmosferom (Eames i MacDaniels, 1925; Weberling, 1989; Borowska-Wykręt i Kwiatkowska, 2018). Puči su na laticama rijetko prisutne (Fahn, 1982; Weberling, 1989).

Iako se u većine cvjetova epidermalne stanice čunjasto izbočuju na površini latice, ima i vrsta kod kojih je ispupčenje okrenuto prema mezofilu (tj. unutrašnjosti latice), dok je vanjska stijenka ravna ili samo blago kupolasto izbočena (Kay et al., 1981). Takav "obrnuto čunjast” oblik epidermalnih stanica utvrđen je npr. u latica Poscharskyjevog zvončića (Campanula poscharskyana Degen) (Kay et al., 1981). U slučaju kada su epidermalne stanice latica produljene, one mogu imati i više čunjastih ili kupolastih izbočenja, pri čemu izbočenja mogu biti okrenuta prema površini latice i/ili prema mezofilu. Takve "višestruko čunjaste" stanice nađene su primjerice kod krivičice (Anagallis monelli L.) (Quintana et al., 2007), šafrana (Crocus sp.) te vrsta por. Cistaceae (Kay et al., 1981; Argiropoulos i Rhizopoulou, 2012).

Kutikula je gotovo uvijek prisutna na laticama, iako se njena debljina kod različitih vrsta može razlikovati (Eames i MacDaniels, 1925). Kod više od 50\% vrsta kritosjemenjača površina kutikule latica nije glatka, već tvori nabore (Kay et al., 1981). Ovi se nabori često pružaju međusobno paralelno (pri čemu mogu biti položeni u smjeru dulje osi stanice ili okomito na nju) (slika 4b), no katkada formiraju i kompleksnije oblike (Antoniou Kourounioti et al., 2012). Kod stanica čunjasta oblika nabori kutikule pružaju se od bazalnog dijela prema vrhu papile (Kay et al., 1981).

Između adaksijalne i abaksijalne epiderme nalazi se mezofil kroz koji prolaze nježni provodni snopovi. U laticama mezofil većinom nije diferenciran na palisadni i spužvasti parenhim (Weberling, 1989; Nikolić, 2017). Uobičajeno se sastoji od tek nekoliko slojeva stanica (tri do četiri, rjeđe više), a u latica nježne građe može sadržavati i samo jedan do tri nejasno razlučena sloja (Eames i MacDaniels, 1925; Nikolić, 2017). Stanice mezofila često su vrlo rahlo raspoređene te je mezofil tada bogat velikim, zrakom ispunjenim međustaničnim prostorima (Slika 1a). Mezofilne stanice su u poprečnom presjeku obično okruglaste, no u rahlo građenom mezofilu one mogu biti nepravilnog oblika s ispupčenjima preko kojih su stanice u međusobnom kontaktu (Kay et al., 1981; Weberling, 1989; Sulborska et al., 2012).

Pigmenti se u stanicama latica tipično pohranjuju u kromoplastima (karotenoidi) ili u staničnom soku u vakuoli (antocijanini i drugi flavonoidi te betalaini) (Slika 1). Karotenoidi se uglavnom nakupljaju u epidermalnim stanicama, dok su u mezofilu prisutni u znatno manjoj količini. Pigmenti koji se 
nakupljaju u vakuoli kod većine su latica uglavnom ograničeni na epidermu te ih u mezofilnim stanicama nema ili ih ima vrlo malo. U nekih su cvjetova međutim znatne količine antocijanina prisutne u mezofilu latice. Primjerice, kod nekih članova por. Boraginaceae (npr. Myosotis) antocijanini se nalaze $\mathrm{u}$ subepidermalnom sloju, dok epidermalne stanice sadrže bezbojne flavonoide koji apsorbiraju svjetlost u UV području spektra (Kay et al., 1981). Kod orhideja iz roda Dendrobium antocijanini se u cvjetova bljeđih boja nalaze u epidermalnom i subepidermalnom sloju tepala, dok su kod intenzivnije obojenih cvjetova prisutni i dublje u mezofilu (Mudalige et al., 2003).

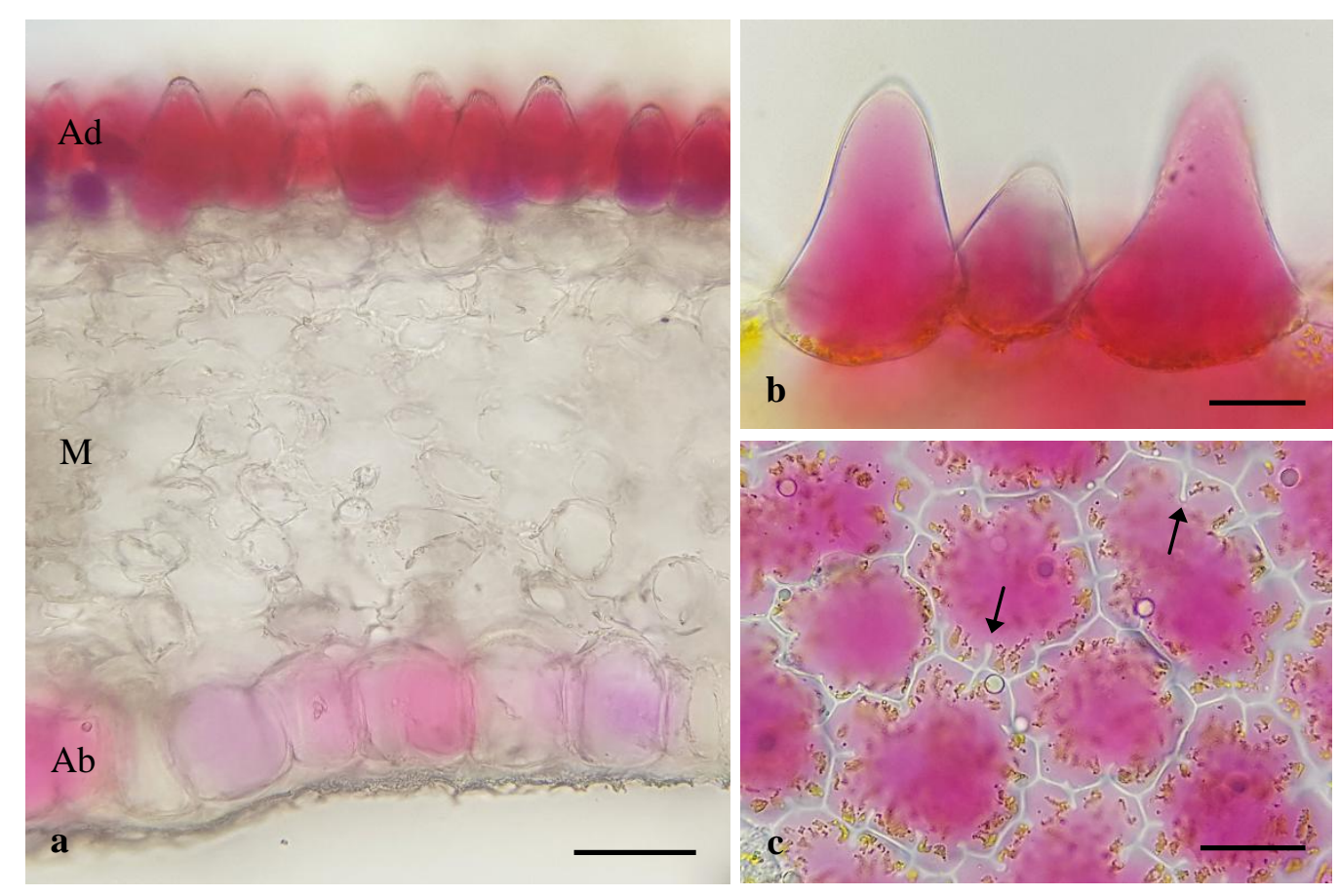

Slika 1. Anatomske karakteristike latica. (a) Poprečni prerez kroz laticu ruže (Rosa x hybrida 'Grande Amore'). Adaksijalna epiderma građena je od stanica čunjasta oblika. Mezofil latice je rahlo tkivo s velikim međustaničnim prostorima. Stanice obje epiderme sadrže antocijanine. Skala $=50 \mu \mathrm{m}$. Izvor: Benšek (2020). (b) Čunjaste epidermalne stanice na adaksijalnoj strani latice jaglaca (Primula vulgaris 'Tiara Red'). Skala $=20 \mu \mathrm{m}$. (c) Abaksijalna epiderma latice jaglaca (Primula vulgaris 'Tiara Rose Orange Bicolor'). Skala $=20 \mu \mathrm{m}$. Strelice označavaju uvrnuća stanične stijenke. Ad - adaksijalna epiderma, Ab - abaksijalna epiderma, $\mathrm{M}$ - mezofil.

Figure 1. Anatomical characteristics of petals. (a) Cross-section of the petal of rose (Rosa x hybrida 'Grande Amore'). The adaxial epidermis is built of conically-shaped cells. Petal mesophyll consists of a loose tissue with large intercellular spaces. The cells of both epidermal layers contain anthocyanins. Scale bar $=50 \mu \mathrm{m}$. From: Benšek (2020). (b) Conical epidermal cells on the adaxial side of the petal of primrose (Primula vulgaris 'Tiara Red'). Scale bar $=20 \mu \mathrm{m}$. (c) Abaxial epidermis of the petal of primrose (Primula vulgaris 'Tiara Rose Orange Bicolor'.) Scale bar $=20 \mu \mathrm{m}$. Arrows indicate invaginations of the cell wall. Ad - adaxial epidermis, Ab-abaxial epidermis, $M$ - mesophyll. 


\section{Utjecaj anatomske građe na boju latica}

\section{Uloga epidermalnih stanica}

Iako boju latica primarno određuju sastav i koncentracija pigmenata, na karakteristike boje mogu utjecati i drugi čimbenici, među kojima važnu ulogu imaju i anatomske značajke tkiva latica, osobito epiderme (Kay et al., 1981; Lee, 2010). Istraživanja provedena na cvjetovima zijevalice (Antirrhinum majus L.) pokazala su da epidermalne stanice čunjasta oblika mogu pojačati intenzitet boje latica (Noda et al., 1994; Gorton i Vogelmann, 1996). Cvjetovi divljeg tipa zijevalice imaju ljubičastocrvene latice, a epidermalne stanice na njihovoj adaksijalnoj strani su, kao i kod cvjetova mnogih drugih vrsta, čunjasto ispupčene. Međutim, kod zijevalice s mutacijom u genu MIXTA ${ }^{3}$ vanjske stijenke epidermalnih stanica nisu čunjasta oblika, već tek blago kupolasto izbočene pa više nalikuju onima u epidermi listova (Gorton i Vogelmann, 1996). Cvjetovi ovog mutanta nisu ljubičastocrveni, kao kod divljeg tipa, već bljeđe, ružičaste boje. Pretpostavlja se da do ove razlike u boji cvjetova dolazi iz nekoliko razloga:

(1) Čunjasto ispupčene epidermalne stanice divljeg tipa zijevalice više su od blago zaobljenih epidermalnih stanica mutanta pa se zbog toga kod divljeg tipa produljuje i put zraka svjetlosti kroz pigmentima ispunjenu vakuolu (Gorton i Vogelmann, 1996).

(2) Bilo koja konveksna prozirna struktura čiji je indeks loma veći od indeksa loma zraka potencijalno može fokusirati svjetlost (tj. djelovati kao sabirna leća) (Slika 2a). Stoga će se, kada paralelan snop zraka svjetlosti padne na površinu stanice $\mathrm{s}$ ispupčenim stijenkama, zbog loma svjetlosti put zraka promijeniti, a prelomljene zrake sastati u jednoj točki (žarištu) u tkivu latice (Vogelmann, 1993). Istraživanja koja su na cvjetovima zijevalice proveli Gorton i Vogelmann (1996) pokazala su da epidermalne stanice latica i u divljeg tipa i u mutanta razmjerno snažno fokusiraju svjetlost. Međutim, za razliku od divljeg tipa zijevalice, kod kojega čunjaste epidermalne stanice svjetlost fokusiraju u vakuole ispunjene antocijaninima, kod mutanta se žarišna ravnina nalazi u nepigmentiranom mezofilu te stoga manje svjetlosti prolazi kroz središnji dio epidermalnih stanica u kojem se nalazi vakuola.

(3) Refleksija svjetlosti na laticama s čunjastim epidermalnim stanicama znatno je manja nego na onima s ravnom epidermom, osobito kada svjetlost pada koso na površinu latica (Slika 2). Zbog toga u divljeg tipa zijevalice veći dio upadne svjetlosti ulazi u epidermalne stanice i dolazi do pigmenata, što laticama daje intenzivniju boju (Kay et al., 1981; Noda et al., 1994; Lee, 2010). Kod latica čije epidermalne stanice nisu ispupčene, već je površina epiderme ravna, refleksija svjetlosti je razmjerno velika (slika 2b). Kod takvih će latica manji dio upadne svjetlosti ući u tkivo i proći kroz stanice s pigmentima nego kod latica s čunjasto ispupčenim epidermalnim stanicama (Kay et al., 1981; Papiorek et al., 2014).

\footnotetext{
${ }^{3}$ Kodira transkripcijski faktor neophodan za razvoj čunjasto ispupčenih stanica u epidermi latica zijevalice.
} 


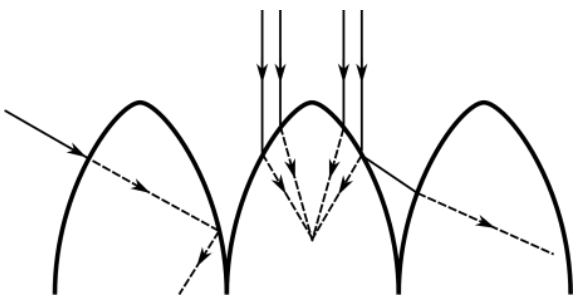

$\mathbf{a}$

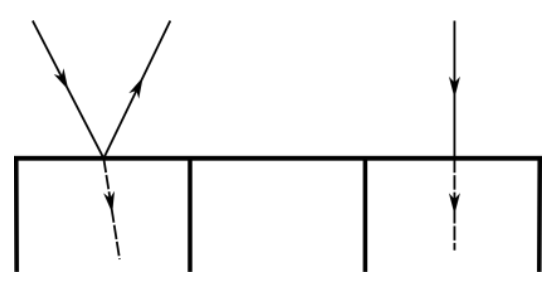

b

Slika 2. Lom i odbijanje zraka svjetlosti na površini čunjasto ispupčenih stanica (lijevo) i stanica s ravnom vanjskom stijenkom (desno). Prema: Vignolini et al. (2013a).

Figure 2. Refraction and reflection of light on the surface of conically-shaped cells (left) and cells with flat outer walls (right) (after Vignolini et al., 2013a).

Na optička svojstva površine latice, međutim, ne utječe samo oblik epidermalnih stanica, već i mikromorfologija kutikule. Različiti oblici epidermalnih stanica u kombinaciji s određenim mikromorfološkim karakteristikama kutikule mogu stvoriti različite optičke efekte. Primjerice, zanimljiv vizualni efekt može nastati kada su vanjske stijenke epidermalnih stanica ravne, a kutikula gradi dugačke nabore. Ako se nabori kutikule nalaze na određenoj međusobnoj udaljenosti i pružaju u dugačkim linijama na dovoljno uređen način, oni tada na zrake svjetlosti djeluju kao optička rešetka uslijed čega može doći do pojave iridescencije ${ }^{4}$ (Glover i Whitney, 2010; Antoniou Kourounioti et al., 2013). Takav je slučaj opisan kod tulipana (Tulipa sp.) i mjehuraste sljezolike (Hibiscus trionum) kod kojih su u dijelovima ocvijeća na kojima se opaža iridescencija epidermalne stanice produljene, s ravnim vanjskim stijenkama, a kutikula koja ih prekriva stvara niz dugačkih, pravilno poredanih nabora koji djeluju kao optička rešetka (Antoniou Kourounioti et al., 2013; Vignolini et al., 2014). Iridescencija je u cvjetova do sada opažena kod tek nekoliko vrsta, a njeno značenje u vizualnoj komunikaciji s oprašivačima još nije sasvim razjašnjeno (Whitney et al., 2009; van der Kooi et al., 2014; van der Kooi et al., 2015; van der Kooi et al., 2019). Ova pojava međutim može pridonijeti vizualnoj atraktivnosti cvjetova ukrasnih biljaka, kao što je to slučaj kod kultivara tulipana 'Queen of the Night' (Vignolini et al., 2013b) (Slika 3).

\footnotetext{
${ }^{4}$ Kada bijela svjetlost pada na optičku rešetku, rastavlja se u spektar boja, koje će, ovisno o njihovoj valnoj duljini, stvarati konstruktivnu interferenciju pod različitim kutovima u odnosu na središnju os rešetke. Stoga se kod latica koje pokazuju svojstvo iridescencije boja koju opažamo mijenja kako se mijenja kut pod kojim ih se promatra ili osvjetljava.
} 


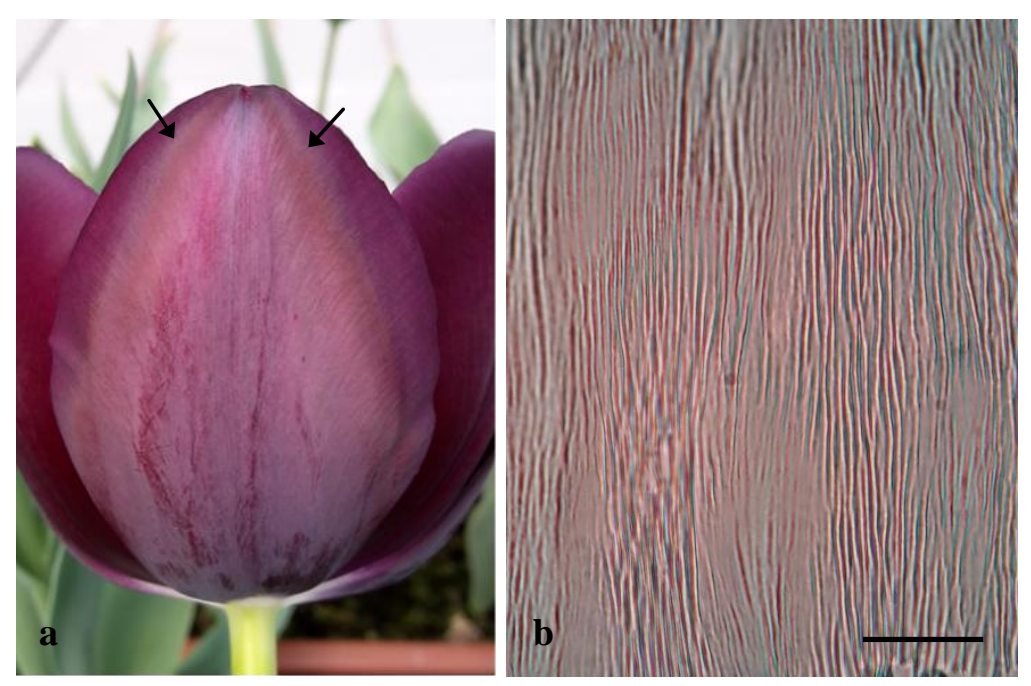

Slika 3. Iridescencija na tepalima kultivara tulipana 'Queen of the Night' (a) Otvoreni cvijet. Na površini tepala vidljiva je iridescencija (strelice). (b) Otisak površine tepala na kojem su vidljivi uzdužno poredani nabori koje stvara kutikula. Skala $=20 \mu \mathrm{m}$. Izvor: Babić, K. (2016).

Figure 3. Iridescence on the tepals of the tulip cultivar 'Queen of the Night' (a) Open flower. Iridescence is visible on the surface of the tepal (arrows). (b) Impression of tepal surface showing longitudinal cuticular ridges. Scale bar $=20 \mu \mathrm{m}$. From: Babić, K. (2016).

\section{Uloga mezofila}

Mezofil latica obično je rahlo tkivo u kojem se upadna svjetlost koja prođe kroz epidermu latica reflektira natrag prema stanicama epiderme gdje ovu svjetlost mogu apsorbirati pigmenti. Do refleksije svjetlosti u mezofilu dolazi na graničnoj površini između stanične stijenke mezofilnih stanica i zrakom ispunjenih međustaničnih prostora (Kay et al., 1981). Zbog toga tipični rahli mezofil latica kada se odvoji od epiderme obično izgleda bijelo ili gotovo bijelo (Kay et al., 1981). Tako i kod bijelih latica, koje ne sadrže pigmente koji apsorbiraju svjetlost u vidljivom području spektra, bijela boja nastaje zbog refleksije svjetlosti u unutrašnjosti latica; ako se međustanični prostori u mezofilu ispune vodom, bjelina se gubi te latice postaju gotovo prozirne (Stickland, 1974).

\section{Utjecaj anatomske građe na vizualne karakteristike površine latica}

Vizualne karakteristike površine (tekstura) latica važan su element dekorativnosti cvjetova koji, za razliku od boje, uz vizualnu uključuje i taktilnu komponentu (Slika 4a i b). Pored toga, tekstura utječe i na doživljaj boje: latice iste boje, ali drugačije teksture mogu stvarati drugačiji vizualni dojam (Zhang et al., 2008).

Kod nekih cvjetova površina latica je sjajna, a sjaj može biti i prilično izražen ako je površina epiderme vrlo ravna i glatka (Kay et al., 1981; Vignolini et al., 2011; Vignolini et al., 2012; Papiorek 
et al., 2014; van der Kooi et al., 2019). No, takvih je cvjetova razmjerno malo. Kod većine vrsta epidermalne stanice latica su čunjasto ispupčene (Kay et al., 1981), a latice imaju slabo izražen sjaj. Smatra se da epidermalne stanice čunjasta oblika raspršuju svjetlost koja se reflektira iz mezofila ravnomjernije nego stanice ravnih vanjskih stijenki (slika 4c), što površini latica daje matirani izgled, a katkada i baršunastu teksturu (Kay et al., 1981; Noda et al., 1994; Whitney et al., 2011; van der Kooi et al., 2014). Opsežno istraživanje koje su Zhang et al. (2015) proveli na 19 različitih ukrasnih vrsta i križanaca pokazalo je da su kod latica baršunastog izgleda epidermalne stanice čunjastog ili kupolastog oblika. Međutim, svi cvjetovi s baršunastim laticama bili su tamnih boja što upućuje na zaključak da je drugi važan čimbenik koji pridonosi baršunastoj teksturi visoka koncentracija pigmenata. Primjerice, kod kultivara maćuhice s bijelim i tamnoljubičastim laticama, baršunastu površinu imala je ljubičasta latica, no ne i bijela, iako se epidermalne stanice među ovim laticama oblikom nisu razlikovale (Zhang et al., 2015).

Smatra se da na teksturu latica, uz oblik epidermalnih stanica, može utjecati i građa mezofila (Mudalige et al., 2003; Zhang et al., 2008). Primjerice, u istraživanju koje su Mudalige i sur. (2003) proveli na cvjetovima orhideja iz roda Dendrobium, tepali s ravnom površinom epiderme i gusto raspoređenim mezofilnim stanicama imali su sjajnu površinu, dok su tepali s kupolasto izbočenim epidermalnim stanicama i rahlim mezofilom bili baršunaste površine (Mudalige et al., 2003).
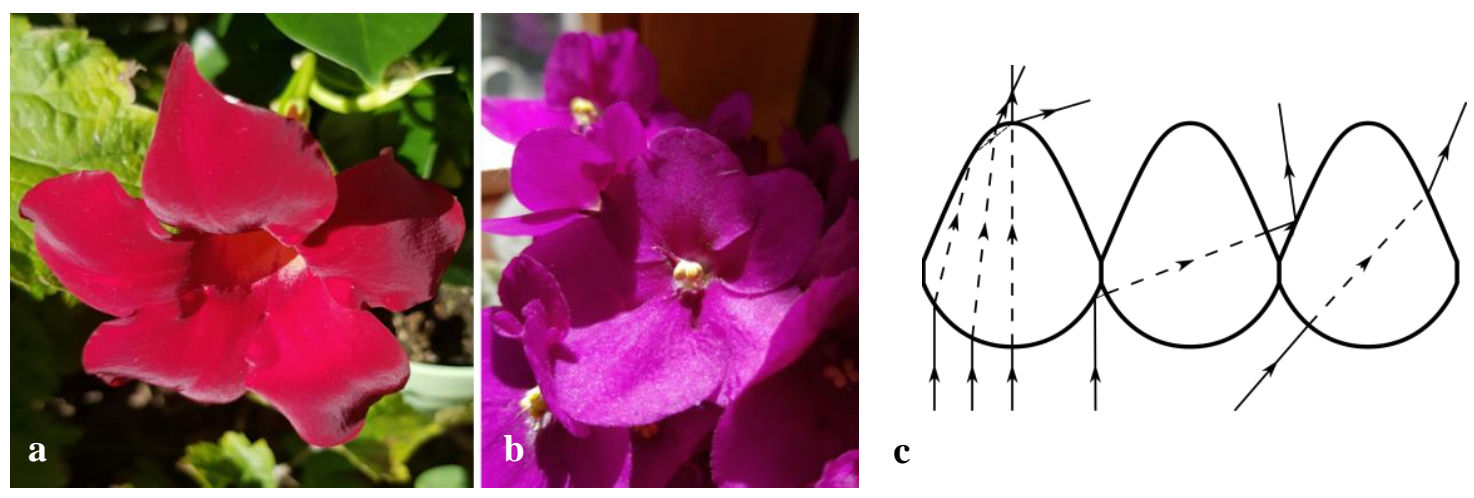

Slika 4. (a-b) Primjeri različitih vizualnih karakteristika površine latica. (a) Cvijet mandevile (Mandevilla sanderi) s laticama baršunaste površine. (b) Cvjetovi afričke ljubičice (Saintpaulia ionantha) s laticama svjetlucave površine. (c) Putovi zraka svjetlosti reflektiranih iz mezofila kroz epidermalne stanice čunjasta oblika. Prema: Kay et al. (1981).

Figure 4. (a-b) Examples of different visual characteristics of petal surface. (a) Velvety petals in the flower of rocktrumpet (Mandevilla sanderi). (b) Sparkling appearance of petal surface in the flowers of African violet (Saintpaulia ionantha). (c) Paths of light rays reflected from the petal mesophyll through the conically-shaped epidermal cells (after Kay et al., 1981). 


\section{Zaključak}

Vizualne karakteristike latica jedan su od osnovnih elemenata ukrasne vrijednosti cvjećarskih kultura. Premda boju latica primarno određuju pigmenti, na njene karakteristike mogu utjecati i anatomske značajke tkiva latica, posebice oblik epidermalnih stanica. Čunjast oblik epidermalnih stanica može povećati količinu svjetlosti koja dolazi do pigmenata, uslijed čega se pojačava i intenzitet boje. Građa tkiva međutim, osim na boju, utječe i na vizualne karakteristike površine latica. Primjerice, čunjaste epidermalne stanice laticama tamnih boja mogu dati vrlo dekorativan baršunasti izgled. Pri tome je važno uzeti u obzir da se estetska svojstva teksture latice ne temelje samo na njenim vizualnim obilježjima, već i na tome kako ona utječe na doživljaj boje.

\section{Literatura}

Antoniou Kourounioti, R.L., Band, L.R., Fozard, J.A., Hampstead, A., Lovrics, A., Moyroud, E., Vignolini, S., King, J.R., Jensen, O.E., Glover, B.J. (2013). Buckling as an origin of ordered cuticular patterns in flower petals. Journal of the Royal Society Interface, 10, 20120847, http://dx.doi.org/10.1098/rsif.2012.0847.

Argiropoulos, A., Rhizopoulou, S. (2012). Topography and nanosculpture of petals' surfaces of shortlived flowers of the wild species Cistus creticus, Cistus salviifolius, Eruca sativa and Sinapis arvensis. Botanical Studies, 53 (4), 479-488.

Babić, K. (2016). Anatomske i mikromorfološke karakteristike tepala tulipana. Agronomski fakultet Sveučilišta u Zagrebu, diplomski rad.

Behe, B.K., Nelson, R., Barton, S., Hall, C., Safley, C.D., Turner, S. (1999). Consumer preferences for geranium flower color, leaf variegation, and price. HortScience, 34, 740-742.

Behe, B.K., Redman, P.B., Dole, J.M. (1997). Consumers prefer red poinsettia cultivars. HortTechnology, 7 (4), 438-441.

Benšek, V. (2020). Anatomske karakteristike latica odabranih kultivara ruže (Rosa hybrida L.). Agronomski fakultet Sveučilišta u Zagrebu, diplomski rad.

Borowska-Wykręt, D., Kwiatkowska, D. (2018). Folding, wrinkling, and buckling in plant cell walls. In Geitmann, A., Gril J. (eds.). Plant Biomechanics. Cham: Springer, 209-233.

Boutigny, A.L., Dohin, N., Pornin, Rolland, M. (2020) Overview and detectability of the genetic modifications in ornamental plants. Horticultural Research, 7, 11, https://doi.org/10.1038/s41438-0190232-5. 
Coherent Market Insights (2019). Floriculture Market Report, by Product Type (Cut Flowers, Pot Plants, Cut Foliage, Bedding Plants, and Others), by Application (Decoration and Industrial), and by Region (North America, Latin America, Asia Pacific, Europe, and Middle East \& Africa) - Size, Share, Trends and Forecast 2019-2027. Dostupno na: https://www.coherentmarketinsights.com (posjećeno 10.6.2021.).

Eames, A.J., MacDaniels, L.H. (1925). An Introduction to Plant Anatomy. $1^{\text {st }}$ ed. New York and London: McGraw-Hill Book Company.

Europe Cut Flowers Market (2020). Europe Cut Flowers Market Forecast to 2027 - COVID-19 Impact and Regional Analysis by Flower Type, and Application. Dostupno na: https://www.researchandmarkets.com/reports/5231498/europe-cut-flowers-market-forecast-to-2027 (posjećeno 10.6.2021.).

Fahn, A. (1982). Plant Anatomy. $3^{\text {rd }}$ ed. Oxford: Pergamon Press.

Giovannini, A., Laura, M., Nesi, B., Savona, M., Cardi, T. (2021). Genes and genome editing tools for breeding desirable phenotypes in ornamentals. Plant Cell Reports, 40, 461-478.

Gkikas, D., Argiropoulos, A., Rhizopoulou, S. (2015). Epidermal focusing of light and modelling of reflectance in floral-petals with conically shaped epidermal cells. Flora, 212, 38-45.

Glover, B.J., Whitney, H.M. (2010). Structural colour and iridescence in plants: the poorly studied relations of pigment colour. Annals of Botany, 105 (4), 505-511.

Gorton, H.L., Vogelmann, T.C. (1996). Effects of epidermal cell shape and pigmentation on optical properties of Antirrhinum petals at visible and ultraviolet wavelengths. Plant Physiology, 112 (3), 879-888.

Iwashina, T. (2015). Contribution to flower colors of flavonoids including anthocyanins: a review. Natural Product Communications, 10 (3), 529-544.

Kay, Q.O.N., Daoud, H.S., Stirton, C.H. (1981). Pigment distribution, light reflection and cell structure in petals. Botanical Journal of the Linnean Society, 83 (1), 57-83.

Kelley, K.M., Behe, B.K., Biernbaum, J.A., Poff, K.L. (2001). Consumer preference for edible-flower color, container size, and price. HortScience, 36, 801-804.

Kishimoto, S., Sumitomo K., Yagi, M., Nakayama, M., Ohmiya, A. (2007). Three routes to orange petal color via carotenoid components in 9 Compositae species. Journal of the Japanese Society for Horticultural Science, 76 (3), 250-257. 
Lee, D. (2010). Nature's Palette: The Science of Plant Color. Chicago: University of Chicago Press.

Młodzinska, E. (2009). Survey of plant pigments: Molecular and environmental determinants of plant colors. Acta biologica Cracoviensia, Series botanica, 51 (1), 7-16.

Mol, J., Grotewold, E., Koes, R. (1998) How genes paint flowers and seeds. Trends in Plant Science, $3(6), 212-217$.

Mudalige, R.G., Kuehnle, A.R., Amore, T.D. (2003). Pigment distribution and epidermal cell shape in Dendrobium species and hybrids. HortScience, 38 (4), 573-577.

Nakayama, M., Okada, M., Taya-Kizu, M., Urashima, O., Kan, Y., Fukui, Y., Koshioka, M. (2004). Coloration and anthocyanin profile in tulip flowers. Japan Agricultural Research Quarterly, 38 (3), $185-190$.

Nikolić, T. (2017). Morfologija biljaka. Zagreb: Alfa.

Noda, K.-I., Glover, B.J., Linstead, P. and Martin, C. (1994). Flower colour intensity depends on specialized cell shape controlled by a Myb-related transcription factor. Nature, 369, 661-664.

Ohimya, A. (2011). Diversity of carotenoid composition in flower petals. Japan Agricultural Research Quarterly, 45 (2), 163-171.

Ohimya, A. (2018). Molecular mechanisms underlying the diverse array of petal colors in chrysanthemum flowers. Breeding Science, 68 (1), 119-127.

Papiorek, S., Junker, R.R., Lunau, K. (2014). Gloss, colour and grip: multifunctional epidermal cell shapes in bee- and bird-pollinated flowers. PLOS ONE, 9 (11), e112013. https://doi.org/10.1371/journal.pone.0112013

Pavoković, D., Krsnik-Rasol, M. (2011). Complex biochemistry and biotechnological production of betalains. Food Technology and Biotechnology, 49 (2), 145-155.

Polturak, G., Aharoni, A. (2018). "La vie en rose": biosynthesis, sources, and applications of betalain pigments. Molecular Plant, 11 (1), 7-22.

Quintana, A., Albrechtová, J., Griesbach, R.J., Freyre, R. (2007). Anatomical and biochemical studies of anthocyanidins in flowers of Anagallis monelli L. (Primulaceae) hybrids. Scientia Horticulturae, $112(4), 413-421$.

Royal FloraHolland (2020). Facts \& Figures 2020. Dostupno na: www.floraholland.com (posjećeno: 11.6. 2021.) 
Schreiber, H.D., Swink, A.M., Godsey, T.D. (2010). The chemical mechanism for $\mathrm{Al}^{3+}$ complexing with delphinidin: a model for the bluing of hydrangea sepals. Journal of Inorganic Biochemistry, 104 (7), 732-739.

Stavenga, D.G., Staal, M., van der Kooi, C.J. (2020). Conical epidermal cells cause velvety colouration and enhanced patterning in Mandevilla flowers. Faraday Discussions, 223, 98-106.

Stickland, R.G. (1974). The nature of white colour of petals. Annals of Botany, 38(5), 1033-1037.

Sulborska, A., Weryszko-Chmielewska, E., Chwil, M. (2012). Micromorphology of Rosa rugosa Thunb. petal epidermis secreting fragrant substances. Acta Agrobotanica, 65(4), 21-28.

Tanaka, Y., Sasaki, N., Ohmiya, A. (2008). Biosynthesis of plant pigments: anthocyanins, betalains and carotenoids. The Plant Journal, 54 (4), 733-749.

Van der Kooi, C.J., Wilts, B.D., Leertouwer, H.L., Staal, M., Elzenga, J.T., Stavenga, D.G. (2014). Iridescent flowers? Contribution of surface structures to optical signaling. New Phytologist, 203 (2), $667-73$.

van der Kooi, C.J., Dyer, A.G., Stavenga, D.G. (2015). Is floral iridescence a biologically relevant cue in plant-pollinator signaling? New Phytologist, 205 (1), 18-20.

van der Kooi, C.J., Elzenga, J.T.M., Staal, M. Stavenga, D.G. (2016). How to colour a flower: on the optical principles of flower coloration. Proceedings of the Royal Society B 283, 20160429, https://doi.org/10.1098/rspb.2016.0429.

van der Kooi, C.J., Dyer, A.G., Kevan, P.G., Lunau, K. (2019). Functional significance of the optical properties of flowers for visual signalling. Annals of Botany, 123 (2), 263-276.

Vignolini, S., Glover, B.J., Steiner, U. (2013a). Photonic structures in plants. In Pyke, E. R., Brown, R.G.W. (eds.). Biomimetics in Photonics. Boca Raton: CRC Press.

Vignolini, S., Moyroud, E, Glover, B.J., Steiner, U. (2013b). Analysing photonic structures in plants. Journal of the Royal Society Interface, 10, 20130394-20130399, https://doi.org/10.1098/rsif.2013.0394.

Vignolini, S., Moyroud, E., Hingant, T., Banks, H., Rudall, P.J., Steiner, U., Glover, B. (2014). The flower of Hibiscus trionum is both visibly and measurably iridescent. New Phytologist, 205 (1), 97-101.

Vignolini, S., Davey, M.P., Bateman, R.M., Rudall, P.J., Moyroud, E., Tratt, J., Malmgren, S., Steiner, U., Glover, B.J. (2012). The mirror crack'd: both pigment and structure contribute to the glossy blue appearance of the mirror orchid, Ophrys speculum. New Phytologist, 196(4), 1038-1047. 
Vignolini, S., Thomas, M.M., Kolle, M., Wenzel, T., Rowland, A., Rudall, P.J., Baumberg, J.J., Glover, B.J., Steiner, U. (2011). Directional scattering from the glossy flower of Ranunculus: how the buttercup lights up your chin. Journal of the Royal Society Interface, 9, 1295-1301.

Vogelmann, T.C. (1993). Plant tissue optics. Annual Reviews of Plant Physiology and Plant Molecular Biology, 44, 231-51.

Waliczek T. M., Byrne D., Holeman D. (2018). Opinions of landscape roses available for purchase and preferences for the future market. HortTechnology. 28 (6), 807-814.

Weberling, F. (1989). Morphology of Flowers and Inflorescences. Cambridge: Cambridge University Press.

Weryszko-Chmielewska, E., Sulborska, A. (2012) Diversity in the structure of the petal epidermis emitting odorous compounds in Viola $\times$ wittrockiana Gams. Acta Scientiarum Polonorum - Hortorum Cultus, 11 (6), 155-167.

Whitney, H. M., Bennett, K. M., Dorling, M., Sandbach, L., Prince, D., Chittka, L., Glover, B. J. (2011). Why do so many petals have conical epidermal cells? Annals of Botany, 108 (4), 609-616.

Whitney, H.M., Kolle, M., Andrew, P., Chittka, L., Steiner, U., Glover, B.J. (2009). Floral iridescence, produced by diffractive optics, acts as a cue for animal pollinators. Science, 323 (5910), 130-133.

Yoshida, K., Mori, M., Kondo, T. (2009). Blue flower color development by anthocyanins: from chemical structure to cell physiology. Natural Products Reports, 26 (7), 884-915.

Yue, C., Behe, B.K. (2010). Consumer color preferences for single-stem cut flowers on calendar holidays and noncalendar occasions. HortScience, 45 (1), 78-82.

Zhang, Y., Sun, T., Xie, L., Hayashi, T., Kawabata, S., Li, Y. (2015). Relationship between the velvetlike texture of flower petals and light reflection from epidermal cell surfaces. Journal of Plant Research, 128 (4), 623-632.

Zhang, Y., Hayashi, T., Inoue, M., Oyama, Y., Hosokawa, M., Yazawa, S. (2008). Flower color diversity and its optical mechanism. Acta Horticulturae, 766, 469-476.

Primljeno: 09. ožujka 2021. godine

Prihvaćeno: 30 lipnja 2021. godine
Received: March 09, 2021

Accepted: Jun 30, 2021 